\title{
THE STATE OF CIRCULATION OF THE PARENCHYMA OF THE KIDNEY WITH UNILATERAL LESION AND ITS CORRECTION IN THE PERIOPERATIVE PERIOD
}

\section{Viktor Stus ${ }^{1}$ \\ Konstantin Barannik ${ }^{2}$}

DOI: https://doi.org/10.30525/978-9934-588-15-0-72

\begin{abstract}
The aim of this work is to improve the results of complex treatment of patients with unilateral renal injury through the dynamic determination of renal blood flow disorders and its reasonable correction in the perioperative period. Based on the experimental study on 120 white Wistar rats in conditions of stable restriction of blood supply to the kidney parenchyma, acute disturbance of urodynamics, or their combination was reduced blood flow of the parenchyma of the injured kidney in proportion to the degree of pathological process, which occurs in the waveforms with maximum detection on the $3 \mathrm{rd}$ and 7 th -10 th days. These disorders occur most clearly during the first 14 days, followed by stabilization of the process after 1 month. Adaptive-compensatory changes in the blood flow of the opposite kidney give a positive effect, starting from the 14th day, and lasting until the 4th month. Based on a clinical study using ultrasound Doppler and radioisotope studies, 108 patients with unilateral kidney damage were found to have impaired blood flow not only in the affected kidney but also in the opposite. A method of medical correction of disturbed blood flow during the perioperative period was developed and implemented, which allows to improve its quality by $7.8 \%$.
\end{abstract}

\section{Introduction}

Actuality of theme. In urological practice, during the implementation of some surgery on the kidney, there is a need to temporarily stop the renal circulation. In addition, certain pathological conditions (stenosis and acute

\footnotetext{
${ }^{1}$ Doctor of Medical Sciences, Professor, Head of the Department of Urology, Dnepropetrovsk Medical Academy of the Ministry of Health of Ukraine, Ukraine

${ }^{2}$ Candidate of Medical Sciences, Assistant of the Department of Urology,

Dnepropetrovsk Medical Academy of the Ministry of Health of Ukraine, Ukraine
}

(c) Viktor Stus, Konstantin Barannik 
thrombosis of the renal arteries, traumatic lesions, chronic inflammatory processes of the parenchyma, nephrosclerosis, etc.) lead to persistent impaired renal circulation, which causes significant impaired organ function and can even lead to inflammation. et al., 2001; Lyulko O.V. et al., 1999, 2005, 2006; Vozianov S.O. et al., 2013; Pasechnikov S.P. et al., 2010, 2013; Rusin V.I. and et al., 2013), to cause nephrectomy (Saydakova N.O. et al., 2009, 2011, 2013). The paired kidney organ is negatively affected by a pathological process (temporary and permanent ischemia, impaired urodynamics, etc.) that affects one of the kidneys. In this case, the effect of the negative factor applies to both kidneys, which correspond to a number of compensatory-adaptive reactions aimed at maintaining the total function. The degree of severity of these reactions to the direct depends on the degree of damaging effects and applies to both kidneys. Violation of their normal course in the opposite kidney is impeded by the reno-renal reflex (Lyulko O.V. et al., 1997, 2001; Durak V.S. et al., 2010; Boyko A.I. 2003, 2011; Mar R.H. et al., 2007; De Zeeuw D. et al., 2008). A single kidney left after nephrectomy cannot be considered a perfectly healthy organ, as evidenced by the various pathological changes and diseases that occur in it over time. The reason for this is also the imperfection of adaptation reserves. At the heart of all disorders, first of all, are disorders of the renal blood flow and microcirculation in the parenchyma of the organ. They are particularly pronounced in the early hours of the adverse effect of a negative factor, surgery, or injury to the kidney and continue throughout the course of the pathological condition (Vozianov, A.F. et al., 2003; Lyulko, O.V. et al., 2005; Djurak B.S. et al., 2010; Boyko A.I., 2011; Vozianov S.O. et al., 2012; Pasechnikov, S.P. et al., 2010, 2013; Marchenko T.V. et al., 2014). The proposed remedies for the protection of the kidney parenchyma relate to protecting the tissue from insufficient tissue respiration and eliminating (or reducing) disorders of metabolic processes in it (Pirogov V.A. et al., 2013; Vatazin A.V. et al., 2014; Popov S.V. et al., 2014; V.V. Chernenko et al., 2015; Johannes T. et al. 2006; Dietcrich H.J. et al. 2007). The introduction of the immunohistochemical (IGC) method, as a modern highly informative technology, in the diagnosis of human kidney diseases should improve the results of therapeutic interventions by making informed clinical decisions. Development of prognostic and diagnostic IGC criteria on the models of the most common rat kidney pathologies is the first step to achieve this goal 
(Parfenova E.V. et al. 2002; Serbina I.E. et al. 2013; Bonventure J.V. et al. 2003; Vansthertem D. et al 2008).

Therefore, a thorough study of the primary negative changes in blood flow in the kidneys, their elimination (or prevention) in combination with the proposed is relevant and requires their implementation. Of particular importance are the actions of protecting the contralateral kidney when necessary to remove the affected, in order to improve the compensatory capacity of the remaining single kidney to restore its adequate functional state and prevent the reproduction of pathological changes (diseases) in the subsequent period.

One of the promising directions of improvement of impaired blood flow of the parenchyma of the kidneys with their unilateral lesion is the development and implementation of a method of its perioperative medication correction, as a supplement to adequate operative elimination of the cause of the disease.

Literature review: In urological practice, during the implementation of certain surgical interventions on the kidney, there is a need for a temporary cessation of renal circulation. In addition, certain pathological conditions (stenosis and acute thrombosis of the renal arteries, chronic inflammatory processes of the parenchyma, nephrosclerosis, urolithiasis, etc.) lead to persistent impaired renal circulation, which causes significant impaired organ function, and may lead to organ failure, cause nephrectomy. However, the numerous studies carried out to date on this pressing problem leave a number of insufficiently studied issues, especially concerning the effective protection of the affected organ from the influence of ischemic damage, maximum preservation of its function and ensuring the most effective reproduction of the compensatory and adaptive mechanisms of function restructuring as well as the affected organ. and the opposite kidney. This is especially important when it comes to the only kidney that remains after removal of the affected.

In the future, the importance of organ-preserving operations that eliminate the development or slow the progression of chronic kidney disease and, including, renal insufficiency, will increase. Kidney resection in conditions of total thermal ischemia with renal vascular clamping performed in localized tumors provides oncologic survival of patients in comparison with nephrectomy. The time of ischemia is important in relation 
to the acute damage of the kidney, with its possible transition to a chronic form. According to studies, the time of thermal ischemia is 14-25 minutes. However, the time of ischemia is more than 25 minutes. leads to the development of severe damage to the parenchyma of the operated organ. Clinically proven that the most sensitive indicators of the functional state of the kidneys in the postoperative period were glomerular filtration rate (GFR) and creatinine level. Patients operated on for urological diseases using minimally invasive techniques, to a lesser extent, compared with open surgery, suffer from a functional state of the kidneys.

The kidneys, due to their functional and anatomical features, are an excellent model for the study of hemodynamics, which allows the use of renal artery Doppler ultrasound to determine the extent of organ lesions in systemic diseases. The blood circulation in them is precisely the main adjustable variable that allows the kidneys to adapt to changes in metabolic processes and maintain at any given moment the level of blood flow required for them. In addition, the kidneys account for $19 \%$ of cardiac output. Doppler artery doppleometry as a testimony to the functional state of the kidney and its hemodynamics is widely used in various medical fields. Studies are becoming more widespread due to the high informativeness, non-invasiveness, safety and possibility of repeated use of this method during the disease period.

With the advent of new ultrasonographic methods, attempts have been made to apply them to more general information. Thus, in order to assess the hemodynamics of the kidney in obstructive uropathies, ultrasonic doppleometry of the renal arteries and their branches was applied. For the study of urodynamics, color Doppler mapping was used in combination with pulsed Doppler imaging of urine flows from terminal sections of the ureter.

In the animal experiment, the morphological and functional changes that occur in the parenchyma of the affected and contralateral kidneys under the influence of temporary and permanent ischemia on one of them were studied. Changes in the microcirculatory bed of the fibrous capsule of the kidney under the influence of temporary and permanent ischemia were studied in an experiment in 137 white Wistar lines and 24 stray dogs. During the experiment, it was found that with all types of ischemia, the contralateral kidney is necessarily involved in the pathological process. The resulting changes in the microcirculatory bed are directly proportional to 
the duration and severity of impaired blood supply to the organ. Due to the reno-renal reflex pathological changes occur, which have a phase character. The spasm of the vessels is gradually replaced by their dilation, an increase in the capacity of the capillaries and postcapillary venules that occurs on the 7 th to 10th day (maximum - on the 14th day - after complete cessation of arterial blood flow). The compensatory changes of the blood vessels are joined by changes in the lymphatic capillaries, the cavities of which expand, they take a winding direction, which increases their capacity, and the intensity of coloration of the walls indicates an increase in the intensity of metabolic processes. The stabilization of compensatory and adaptive changes occurs completely after 2 months.

Changes in the renal parenchyma and microcirculatory bed of their fibrous capsule under the influence of temporary ischemia in an experiment in 20 stray dogs were studied. During the experiments, it was found that kidney ischemia during the 1 st and 2 nd hours causes dyscirculatory and dystrophic changes in all departments of the nephrons. The preservation of blood flow in the subcapsular layers of the crustal substance is not sufficient to prevent organic changes in the parenchyma. After 24 hours they undergo dystrophic changes, that is, there is a need for a series of measures to protect the kidney from prolonged exposure to ischemia, even after the resumption of blood perfusion. 1 hour after 2 hours of ischemia, both dyscirculatory and dystrophic changes were expressed in the kidney, which after 24 hours turned into necrotic, which caused a low efficiency of recreational activities in the post-ischemic period.

For the minds of the vidiv ishimii contralateral kidney necessarily get to the pathological process. Emerging changes in the microcirculatory bed and ATPase activity of the renal parenchyma are directly proportional to the time of action and the severity of impaired blood supply. Due to the renorenal reflex pathological changes occur, which have a phase character. The spasm of the vessels gradually changes to their dilation, an increase in the capacity of capillaries and postcapillary venules, which occurs on the 7 th to 10th day (maximum - on the 14th day after the termination of arterial blood flow). Changes in the lymphatic capillaries, the cavity of which expands, are joined to the compensatory remodeling of the blood vessels; There is an adequate change in ATPase activity with compensatory activation of their action in conditions of renal parenchyma ischemia and its consequences. 
The stabilization of the adaptive-compensatory changes is fully completed after 2 months.

Changes in the functional state of the opposite kidney in the conditions of unilateral lesions of the paired organ are evidenced by clinical studies. Thus, the authors presented 4 cases of renal cell carcinoma complicated by obstructive tumors of the interrenal segment of the inferior vena cava. Dynamic rescintigraphy in all cases revealed a more significant impairment of healthy kidney function than the affected tumor. The only method of treatment of this contingent of patients is operative. Similar changes in the functional state of the contralateral kidney were characterized by the condition with unilateral hydronephrosis and urolithiasis.

However, it should be noted that under the influence of ischemia, there are also positive alterations in the ischemic organ that relate to compensatory and adaptive changes. It is known that intact endothelium has anticoagulant activity and provides free blood flow to the blood vessels. But in response to tissue damage, the microvessels spasm, leading to temporary emptying of capillaries and venules. That is, the vasospastic reactions of small vessels, which are thus the first protective reaction in response to damage, begin to play a negative role over a long period. So, it is known that hypoxia is the main stimulus of angiogenesis in the ischemic organ. When the action of proangiogenic factors exaggerates the action of anti-angiogenic, endothelial cells move from physiologically inactive to active state, which leads to the inclusion of the process of angiogenesis. This process is regulated by growth factors and cytokines, as well as by systems of proteolytic enzymes, among which the leading role is played by the fibrinolytic system, which provides local extracellular proteolysis.

In addition, the detected phenomenon of formation of "pericapsular" lymphatic capillaries is versatile and occurs in a number of pathological conditions that cause stagnation of the primary urine in the renal capsule and pericapsular interstitial edema (eg, single kidney, urolithiasis 53) The mechanism of formation of "pericapsular" lymphocapillary consists in the enhanced neovasculogenesis of lymphatic vessels, induced by the overflow of urinary space of the renal capsule and the formation of pericapses. of ulnar outflow in the renal parenchyma in violation of the passage and reabsorption of the primary urine in the system of convoluted nephron tubules. nephron tubules, which creates new possibilities for purposeful management of the 
renal parenchyma drainage process, for example, by acting on the kidneys by physical factors. One of these methods is lymphosorption.

Aim of the study: To improve the results of complex treatment of patients with unilateral renal injury by dynamically detecting the renal blood flow and making a reasonable correction of its disorders in the perioperative period.

The main objectives of the study:

1. To develop an experimental model of dosage persistent impaired renal blood flow in small laboratory animals.

2. To study in the experiment the features of the influence of changes in blood flow of the affected and contralateral kidneys in laboratory animals in different models of unilateral lesions.

3. To study the effect of pathological changes in the blood flow of the kidneys with unilateral lesions on the morphological state of their parenchyma.

4. By methods of Doppler examination and radioisotope renography to study changes in blood flow of the affected and contralateral kidneys with unilateral lesions of the pathological process in patients requiring surgical treatment.

5. To develop and justify the method of perioperative correction of kidney blood flow disorders with unilateral lesion.

6. To analyze the results of clinical application of perioperative correction of renal blood flow disorders in the complex treatment of patients with unilateral kidney damage and to provide recommendations for its implementation.

\section{The state of blood flow in the renal parenchyma in conditions of unilateral ischemia of the kidney}

In an experiment on 30 white mature matured rats of the Wistar line (group A), permanent ischemia of the left kidney was created by fixed flexion of its artery by its own developed technique. The state of blood flow in the parenchyma of both kidneys was determined by the level of ohmic resistance by the method of reography during the first hour after impaired blood flow after 15, 30, 60 minutes intraoperatively, as well as percutaneously after 1, 3, 5, 7, 10, 14 days, and after 1, 2, 4, 6 months. The rheography was performed by the $4 \mathrm{WG}-2 \mathrm{M}$ rheograph. All animals were 
given the same obstruction to the blood supply to the test kidney due to the fixed flexion of the renal artery with an increase in ohmic resistance of $20 \%$ of the ascending value.

Creating an experimental obstruction of blood flow in the left A 1 (experimental) kidney led to dynamic changes in the ohmic resistance of its parenchyma toward a gradual increase. Thus, after 15 minutes the ohmic resistance exceeded the initial level by $63 \pm 8.3 \%$, after 30 minutes by $33.3 \pm 5.1 \%$, after 60 minutes - by $41.4 \pm 3.8 \%$. Such fluctuation of the indicator may indicate changes in the capacity of the vascular bed of the experimental kidney in relation to the reduced amount of blood entering the organ. Changes in the ohmic resistance of the parenchyma of the contralateral kidney A2 have similar fluctuations. Thus, after 15 minutes, the ohmic resistance index increased by $31.3 \pm 2.1 \%$, after 30 minutes - by $26.4 \pm 1.3 \%$, and after 60 minutes - by $21.3 \pm 2.0 \%$. That is, through the reno-renal reflex there are disturbances of blood flow and in the contralateral kidney towards the decrease of its intensity, which cannot immediately compensate for the impaired function of the experimental kidney. The data are given in table 1.

Table 1

Omic resistance (in \%) in the determination of renal blood flow during the first hour of the experiment, $n, M \pm S$

\begin{tabular}{|c|c|c|c|c|}
\hline Group & $\mathbf{n}$ & $\mathbf{1 5}$ min. & $\mathbf{3 0 ~ m i n .}$ & $\mathbf{6 0}$ min. \\
\hline A 1 & 30 & $\begin{array}{c}163 \pm 8,3 \\
\mathrm{p}<0,05\end{array}$ & $\begin{array}{c}183,3 \pm 5,1 \\
\mathrm{p}<0,05\end{array}$ & $\begin{array}{c}141,3 \pm 3,8 \\
\mathrm{p}<0,05\end{array}$ \\
\hline A 2 & 30 & $\begin{array}{c}131,3 \pm 2,1 \\
\mathrm{p}<0,02\end{array}$ & $\begin{array}{c}126,4 \pm 1,3 \\
\mathrm{p}<0,02\end{array}$ & $\begin{array}{c}121,3 \pm 2,0 \\
\mathrm{p}<0,05\end{array}$ \\
\hline KG & 10 & 100 & 100 & 100 \\
\hline
\end{tabular}

The study of blood flow in both kidneys after the creation of a model of permanent ischemia of the right kidney for the next 14 days showed the following changes. Thus, the ohmic resistance of the parenchyma of the test kidney after 1 day increased the upward indicator by $48.3 \pm 2.4 \%$, after 3 days - by $42.2 \pm 2.1 \%$, after 5 days - by $40.3 \pm 3.1 \%$, after 7 days - by $39.1 \pm 1.8 \%$, after 10 days - by $28.3 \pm 1.6 \%$, after 14 days - by $27.3 \pm 1.9 \%$. Therefore, there is a gradual stabilization of blood circulation 
in conditions of insufficient blood supply. Changes in ohmic resistance of the parenchyma of the contralateral kidney during the same period were as follows. Thus, after 1 day the indicator increased by $28.2 \pm 2.1 \%$, after 3 days - by $22.5 \pm 2.6 \%$, after 5 days - by $12.4 \pm 4.1 \%$, after 7 days - the indicator was equal to the ascending one, and since the 10th day it was even less than the ascending one $(21.0 \pm 3.1 \%)$ and after 14 days it was $(-34.2 \pm 2.7 \%)$. Changes in the blood flow in the contralateral kidney indicate the compensatory-adaptive nature of the reactions of the vascular component, which begins to compensate for impaired function, starting from the 7 th day. The data are given in table 2 .

Table 2

Omic resistance (in \%) in the determination of renal blood flow during the first 14 days of the experiment, $n, M \pm S$

\begin{tabular}{|c|c|c|c|c|c|c|c|}
\hline Grup & n & 1 day & 3 day & 5 day & 7 day & 10 day & 14 day \\
\hline A 1 & 30 & $\begin{array}{c}148,3 \pm 2,4 \\
\mathrm{p}<0,02\end{array}$ & $\begin{array}{c}142,2 \pm 2,1 \\
\mathrm{p}<0,02\end{array}$ & $\begin{array}{c}140,3 \pm 3,1 \\
\mathrm{p}<0,05\end{array}$ & $\begin{array}{c}139,1 \pm 1,8 \\
\mathrm{p}<0,02\end{array}$ & $\begin{array}{c}128,3 \pm 1,6 \\
\mathrm{p}<0,01\end{array}$ & $\begin{array}{c}127,3 \pm 1,9 \\
\mathrm{p}<0,02\end{array}$ \\
\hline A 2 & 30 & $\begin{array}{c}128,2 \pm 2,1 \\
\mathrm{p}<0,02\end{array}$ & $\begin{array}{c}122,5 \pm 2,6 \\
\mathrm{p}<0,02\end{array}$ & $\begin{array}{c}112,0 \pm 4,1 \\
\mathrm{p}<0,05\end{array}$ & $\begin{array}{c}101,1 \pm 0,8 \\
\mathrm{p}<0,01\end{array}$ & $\begin{array}{c}79,0 \pm 3,1 \\
\mathrm{p}<0,02\end{array}$ & $\begin{array}{c}65,8 \pm 2,7 \\
\mathrm{p}<0,05\end{array}$ \\
\hline KG & 10 & 100 & 100 & 100 & 100 & 100 & 100 \\
\hline
\end{tabular}

Dynamic studies of blood flow in both kidneys in the long term have yielded the following results. The ohmic resistance of the parenchyma of the experimental kidney after 1 month was $+12,3 \pm 3,4 \%$, after 2 months $+4,1 \pm 2,4 \%$, after 4 months $-+3,9 \pm 1,4 \%$, after 6 months $-+3.8 \pm$ $1.3 \%$. That is, signs of stabilization of the process were determined with a steady decrease in blood flow. The contralateral kidney also determined the completion of the compensation process, with subsequent indicators of ohmic resistance to the parenchyma. After 1 month the indicator was $(-10.2 \pm 2.1 \%)$, after 2 months $-(-8.3 \pm 1.1 \%)$, after 4 months $(-7.9 \pm 0.8 \%)$, after 6 months $-(-7.7 \pm 1.3 \%)$. A slight increase in blood flow in the contralateral kidney compensates for the lack of blood supply to the test kidney. The data are given in table 3 .

Therefore, experimental persistent restriction of blood supply to the kidney parenchyma leads to a decrease in blood flow, which is wavy with oscillations toward increasing the ohmic resistance of the organ parenchyma. These 
Table 3

Omic resistance (in \%) in the determination of renal blood flow in the remote experiment term, $n, M \pm S$

\begin{tabular}{|c|c|c|c|c|c|}
\hline Grup & $\mathbf{n}$ & $\mathbf{1}$ month & 2 month & 4 місяці & 6 місяців \\
\hline А 1 & 30 & $\begin{array}{c}112,3 \pm 3,4 \\
\mathrm{p}<0,05\end{array}$ & $\begin{array}{c}104,1 \pm 2,4 \\
\mathrm{p}<0,02\end{array}$ & $\begin{array}{c}103,9 \pm 3,1 \\
\mathrm{p}<0,05\end{array}$ & $\begin{array}{c}103,8 \pm 1,3 \\
\mathrm{p}<0,02\end{array}$ \\
\hline А 2 & 30 & $\begin{array}{c}89,8 \pm 2,1 \\
\mathrm{p}<0,05\end{array}$ & $\begin{array}{c}91,7 \pm 1,1 \\
\mathrm{p}<0,02\end{array}$ & $\begin{array}{c}92,1 \pm 0,8 \\
\mathrm{p}<0,02\end{array}$ & $\begin{array}{c}92,3 \pm 1,3 \\
\mathrm{p}<0,02\end{array}$ \\
\hline КГ & 10 & 100 & 100 & 100 & 100 \\
\hline
\end{tabular}

disorders occur most clearly during the first 14 days, followed by stabilization of the process after 1 month. Determination of the ohmic resistance of the parenchyma of the experimental kidney at a longer time (up to 6 months) indicates the stability of impaired blood supply. Changes in blood flow in the contralateral kidney showed that during the first hour or even the 3rd day, they did not provide compensation for impaired function of the experimental kidney due to a deficiency of blood flow in the "healthy" kidney. Adaptationcompensatory changes in blood flow give a positive effect, starting from the 7 th day with full compensation on the 14th day. Beginning at 1 month after the creation of ischemia of the experimental kidney, in the contralateral kidney, the blood flow level also stabilizes on the indicators of relative compensation of the lost function of the experimental.

Using radioisotope renography and renal Doppler ultrasound, the blood circulation of the renal parenchyma was determined in 58 patients with unilateral pathological lesions (urolithiasis, obstructive uropathy, ureteral strictures, etc.) requiring surgery. All patients underwent radioisotope renographic and Doppler ultrasound examination of the renal arteries to determine the circulatory status of the renal parenchyma. To determine the status of renal hemodynamics during Doppler ultrasound, such indicators as maximal systolic velocity of arterial flow (Vmax), end diastolic velocity (Vmin) were evaluated. In the analysis of Dopplergrams, the following indices were also determined: resistance index (IR), pulsation index (PI), as well as the systolic-diastolic ratio (DM). In the quantitative analysis of renography, the duration of the vascular segment (20-60 s) was determined; the time to reach the maximum level of the Tmach curve $(3-5 \mathrm{~min})$, the half-life of 131I-hippurane from the kidneys is T1 / 2 (8-12 min). 
Doppler ultrasound examination of the renal artery by the affected kidney and the opposite allowed us to determine the following changes in the circulation of their parenchyma, which are shown. Thus, in all cases from the side of the lesion was determined by a steady decrease in the systolic velocity of the arterial flow in the artery of the affected kidney, which was most pronounced in its distal division, which indicated the prevailing changes in the arteries of the renal parenchyma. If, at the level of the renal artery, Vmax was reduced to $0.80 \pm 0.13 \mathrm{~m} / \mathrm{s}(\mathrm{p}>0.05)$ (control $-0.87 \pm 0.03 \mathrm{~m} / \mathrm{s}$ ), then Vmin at the level of the main stem was $0,25 \pm 0.12 \mathrm{~m} / \mathrm{s}(\mathrm{p}>0.05)$ (control $-0.32 \pm 0.06 \mathrm{~m} / \mathrm{s})$. The systolicdiastolic ratio $(\mathrm{SD})$ was $3.60 \pm 0.23(\mathrm{p}<0.05)$ and was almost 1.5 times higher than the control indicator $(2.70 \pm 0.23)$. Changes also occurred with the index of resistance index (IR), which also increased and was at the level of the renal artery $0.69 \pm 0.09(\mathrm{p}<0.02)$ (control $-0.63 \pm 0.05)$. The ripple index $(\mathrm{PI})$ was $1.06 \pm 0.06(\mathrm{p}<0.02)$ (control $-0.92 \pm 0.06)$, which also exceeded its control value.

An increase in peripheral vascular resistance in unilateral kidney damage, especially in cases of acute obstruction, is associated with an increase in pressure in the bowel-cup system, which can provoke an increase in the level of prostaglandins, as well as other vasoactive substances, which in turn cause vasoconstriction. irritation of the vascular endothelium and additional stimulation of prostaglandins. All this can be determined during the Doppler examination.

The study of hemodynamics of the parenchyma of the affected kidney showed the following changes in parameters. Thus, Vmax on the segmental arteries of the affected kidney was reduced by almost $20 \%$ to $0.42 \pm 0.05 \mathrm{~m} / \mathrm{s}$ (control $-0.52 \pm 0.05 \mathrm{~m} / \mathrm{s}$ ), and at the level of the longitudinal arteries by almost $10 \%$ - up to $0.24 \pm 0.04 \mathrm{~m} / \mathrm{s}$ (control $-0.34 \pm 0.04 \mathrm{~m} / \mathrm{s}$ ). At the same time, indicators of resistance index and pulse index also decreased. At the level of segmental arteries, the IR values were $-0.47 \pm 0.08$ (control $-0.60 \pm$ 0.04 ) and $0.41 \pm 0.08$ (control $-0.58 \pm 0.05$ ) at the level of the interparticular arteries of the parenchyma. PI was at the level of segmental arteries $0.62 \pm 0.09$ (control $-0.89 \pm 0.09$ ) and $0.42 \pm 0.08$ (control $-0.83 \pm 0.08$ ) at the level of the intercostal arteries parenchyma. The relative decrease in the index compared to the resistance index at the level of the distal renal artery is associated with the discharge of blood through the arteriovenous 
shunts. The changes in the indices of the blood flow of the kidney with unilateral lesion in it, taking into account the age changes in the vessels with a decrease in their elasticity, corresponded to the degree of lesion and age of patients. Consequently, the lesions of the kidney by any pathological process (urolithiasis, obstructive uropathy, strictures of the ureter, etc.) cause changes in blood flow, which are determined by the method of Doppler. The index of resistance undergoes special changes. At the same time, changes in other indicators of blood flow were not fundamental and did not always coincide with the anatomical and functional changes of the affected kidney.

Radioisotope renographic examination showed almost similar changes in blood flow deterioration in the affected kidney. Thus, the duration of the vascular segment was $67 \pm 2.4 \mathrm{~s}$ (norm $-20-60 \mathrm{~s}$ ), the time to reach the maximum level of the Tmax curve was $8 \pm 1.1 \mathrm{~min}$. (normal $-3-5 \mathrm{~min}$.), half-life of 131I-hippurane from the kidneys - T1 / $224 \pm 3,2$ min. (normal8-12 minutes).

It is known that the contralateral kidney assumes the major part of the overall function of the kidneys due to a number of compensatory-adaptive changes in its vascular bed and, accordingly, an increase in functional load. But the opposite kidney also comes under the influence of the reno-renal reflex, which can interfere with the course of the compensatory remodeling of its blood flow. Determination of hemodynamic status of the contralateral kidney showed the following values. Vmax at the level of the renal artery was increased to $0.90 \pm 0.16 \mathrm{~m} / \mathrm{s}(\mathrm{p}>0.02)$ (control $-0.87 \pm 0.03 \mathrm{~m} / \mathrm{s})$, and Vmin at the level of the main stem it was $0,38 \pm 0.11 \mathrm{~m} / \mathrm{s}(\mathrm{p}>0.05)$ (control $-0.32 \pm 0.06 \mathrm{~m} / \mathrm{s}$ ). The increase in blood flow velocity had a pronounced compensatory nature. Minor changes occurred with indicators of resistance index and pulse index. Thus, the IR, which increased slightly and was $0.57 \pm 0.16(\mathrm{p}>0.02)$ at the level of the renal artery (control $0.63 \pm 0.05)$. PI was $0.98 \pm 0.08(\mathrm{p}>0.02)$ (control $0.92 \pm 0.06)$. The latter indicates some discrepancy between the total capacity of the bloodstream of the opposite kidney and the compensatory increase in blood flow velocity.

A study of hemodynamics at the level of the parenchyma of the contralateral kidney showed the following changes in parameters. Thus, Vmax on the segmental arteries of the opposite kidney was increased to $0.58 \pm 0.06 \mathrm{~m} / \mathrm{s}(\mathrm{p}>0.05)($ control $-0.52 \pm 0.05 \mathrm{~m} / \mathrm{s})$, and at the level of longitudinal arteries this figure increased not so clearly and amounted 
to $0.35 \pm 0.04 \mathrm{~m} / \mathrm{s}(\mathrm{p}>0.05)$ (norm $-0.34 \pm 0.04 \mathrm{~m} / \mathrm{s})$. Changes in the index of resistance were also noted. Thus, at the level of segmental arteries, the IR was $0.31 \pm 0.06(p>0.05)$ (control $-0.60 \pm 0.04)$ and remained unchanged at the level of the interparticular arteries, being also $0.31 \pm 0$, $06(p>0.05)$ (control $0.58 \pm 0.05)$. Changes were also noted in PI. At the level of segmental arteries, its value was $0.37 \pm 0.04(\mathrm{p}>0.05)$ (control $0.89 \pm 0.09)$ and $0.38 \pm 0.09(\mathrm{p}>0.05)($ control $-0.83 \pm 0.08)$ at the level of the interparticular arteries of the parenchyma. The decrease in the resistance index corresponds to the relative mismatch of the total capacity even of the compensatory tunnel of the bloodstream of the opposite healthy kidney. However, the compensatory increase of its function is due to the intensive increase of metabolic processes. The most informative indicator of resistance index appeared, changes of which occur gradually and reflect the state of renal blood flow at all levels of the study.

As the diameter of the vessels decreases, the control group gradually decreases. In the affected pathological process, the indicator has a pronounced tendency to decrease due to a significant deterioration of blood flow. In the opposite "healthy" kidney, the decrease in blood flow resistance is compensated by a decrease and remains at the same level in the vessels of the parenchyma, which should ensure an increase in its intensity. A decrease in the resistance index in the contralateral kidney by $10.5 \pm 0.09 \%$ at the level of the renal artery, and almost 2 times $(93.5 \pm 0.06 \%)$ at the level of the segmental and intercostal arteries noted the relative mismatch of the total capacity of the vascular network of the parenchyma even compensatory remodeling channel of the opposite healthy kidney.

Renographic examination of blood flow in the contralateral kidney revealed almost similar compensatory changes in response to persistent disruption of urodynamics in the affected kidney. Thus, the duration of the vascular segment was $42 \pm 3.5 \mathrm{~s}$ (norm 20-60 s), the time to reach the maximum level of the Tmax curve was $4.9 \pm 1.1 \mathrm{~min}$. (normal $-3-5 \mathrm{~min}$.), half-life of 131I-hippurane from the kidneys - T1 / $28 \pm 1,2 \mathrm{~min}$. (normal 8-12 min). Compared with the Doppler data, radioisotope renography showed a compensatory acceleration of blood flow in the contralateral kidney.

Therefore, the methods of Doppler examination and radioisotope renography allow to determine not only changes in the hemodynamics of the kidneys in the conditions of unilateral kidney damage, but also to assess 
the state of compensatory changes in the opposite kidney, which allows to substantiate and determine ways of their correction in complex treatment.

\section{Conclusions and suggestions}

The analysis of the literature sources, carried out preliminary own researches convincingly proved that unilateral defeat of a paired organ of a kidney by any pathological process influences a condition of blood circulation in a kidney parenchyma. Experimental models of persistent restriction of renal parenchyma blood supply, acute disturbance of urodynamics or their combination lead to a decrease in the blood flow of the parenchyma of the damaged kidney in proportion to the pathological process, which occurs wavy with oscillations towards the increase of the maximal resistance of the parenchyma with maximal 7 parenchyma. day. These disorders occur most clearly during the first 14 days, followed by stabilization of the process after 1 month. The latter not only leads to impaired functional status of the affected kidney, but also causes the development of pathological morphological changes of the kidney tissue. Thus, morphological changes of the renal parenchyma of experimental animals under the conditions of long-term effect of the damaging factor (persistent restriction of blood supply to the kidney parenchyma, acute disturbance of urodynamics or their combination) in the distant terms have differences in pathological changes depending on the mechanism of damage. If acute disruption of urodynamics alone or in combination with ischemia led to the development of hydronephrosis and death of the parenchyma, then unilateral ischemia was characterized by a non-uniform increase in the density of blood vessels with a simultaneous sharp decrease in the expression of growth factor of the endothelium of blood vessels, low tolerance of the endothelium. (by dilation). The contralateral kidney also has a negative effect. Thus, changes in blood flow in the contralateral kidney of experimental models of persistent ischemia of the parenchyma of the experimental kidney, acute disturbance of urodynamics, or their combination showed that during the first hour and up to 7-10 days they do not provide enough compensation for the impaired function of the experimental kidney. Adaptation-compensatory changes in blood flow have a positive effect, starting from the 14th day and lasting until the 4th month, when hemodynamic parameters stabilize on the indicators of relative compensation of lost function of the test. The latter becomes a 
negative reason for the slowdown of the compensatory-adaptive reactions to the restoration of the function of the paired organ. Even the kidney, which remains after the removal of the affected, can not fully compensate for the total function and is not "healthy". In unilateral damage to the rat kidneys, due to experimental ischemia or disturbance of urodynamics, or when combined in the contralateral kidney, pathological changes occur, which are manifested in the presence of dystrophic changes in the epithelium of tubules, edema and sclerosis around large vascular tubules, vascular scars, fetal arterioles due to muscle cell hypertrophy, which indicates the presence of signs of renal hypertension in it and may limit the course adequate compensatory-adaptive reactions to the restoration of the functional state of the kidneys. Disruption of blood flow in both kidneys with unilateral lesion is due, first of all, to the pathological impact of the disease on the affected kidney and the development through the reno-renal reflex of persistent spasm of the vessels of the parenchyma of the contralateral kidney (especially in cases of acute disease). The release into the circulation of vasoactive substances causes a number of vascular reactions, alternation of vasoconstriction and vasodilation disrupt the course of adequate adaptive reactions to the restoration of circulation in the kidneys. The additional impact of surgery also affects the adequate recovery of total renal function. There are two ways to positively influence the blood circulation: improving the rheological properties of the blood and preventing or reducing the spasm of the renal parenchyma.

Doppler examination and radioisotope renography performed in patients with unilateral renal injury showed decreased blood flow in the parenchyma of the affected kidney and correlated proportionally with the degree of lesion and age of the patients.

In view of the above, we have developed and tested the following scheme of the perioperative method of correction of blood flow of both kidneys in unilateral lesions requiring surgical intervention. All patients in the study group were treated according to the protocols of care according to the type of disease. Surgery was performed to an adequate extent aimed at eliminating the pathological process and its consequences with intraoperative measures to restore the functional state of the affected kidney. Taking into account the results of clinical investigation of blood flow, experimental data on modeling of pathological conditions with persistent blood flow 
disturbance and urodynamics, the terms of the greatest blood flow disorder were determined: 3rd, 7th-10th, 14th days. For the elimination of spasm of vessels of the renal parenchyma were prescribed drugs in standard dosage, belonging to the group of sympatholytic substances and do not cause adrenolytic effects (Bretilium tosylate, proxane hydrochloride, doxazosin). They were used 3 days before surgery and 2 weeks after surgery. It was mandatory to prescribe anticoagulants (klexan, fraksiparin, dalteparin) before surgery and within 3 days after surgery. In the postoperative period for 2 weeks was prescribed disaggregants in standard dosage (cavinton, trental, pentoxifylline). To control the quality of blood flow recovery in the kidney parenchyma after full activation of patients after surgery on the 10 th to 14 th day, blood flow was studied using ultrasound or radioisotope renography.

Schematic diagram of restorative correction of blood flow in the kidneys is presented in table 4 .

Table 4

Measures of perioperative correction of renal parenchyma blood flow disorders in patients with unilateral lesions

\begin{tabular}{|c|c|c|}
\hline $\begin{array}{c}\text { Stages of the } \\
\text { perioperative period }\end{array}$ & $\begin{array}{c}\text { Determination of renal } \\
\text { parenchyma blood flow }\end{array}$ & $\begin{array}{c}\text { Measures of correction of } \\
\text { blood flow disorders }\end{array}$ \\
\hline Perioperative period & $\begin{array}{c}\text { Ultrasound, radioisotope } \\
\text { renography }\end{array}$ & $\begin{array}{c}\text { Sympatholytic drugs, } \\
\text { disaggregants (up to 3 days) }\end{array}$ \\
\hline Surgery & - & $\begin{array}{c}\text { Anticoagulants } \\
\text { (before surgery) }\end{array}$ \\
\hline $\begin{array}{c}\text { Early postoperative } \\
\text { period (3-5 days) }\end{array}$ & - & $\begin{array}{c}\text { Anticoagulants (3 days), } \\
\text { Sympatholytic drugs, } \\
\text { disaggregators }\end{array}$ \\
\hline $\begin{array}{c}\text { Late postoperative period } \\
\text { (up to 2-3 weeks) }\end{array}$ & $\begin{array}{c}\text { Ultrasound, radioisotope } \\
\text { renography (after 14 days) }\end{array}$ & $\begin{array}{c}\text { Sympatholytic drugs, } \\
\text { disaggregators } \\
\text { (up to 14 days) }\end{array}$ \\
\hline
\end{tabular}

The developed method is used in the treatment of 50 patients with unilateral kidney damage. The results are summarized in Table 4. After the perioperative correction of renal blood flow in patients with unilateral renal injury on the 10th to 14th day, the index of resistance in the renal artery of 
the affected kidney decreased to $0.64 \pm 0.04(\mathrm{p}<0.02)$ against $0.69 \pm 0,09$ $(\mathrm{p}<0.02)$, on segmental arteries the resistance index was $0.43 \pm 0.06(\mathrm{p}<0.02)$ against $0.47 \pm 0.08(\mathrm{p}<0.02)$, and on interlobular arteries was $0.38 \pm 0.14$ $(\mathrm{p}<0.05)$ versus $0.41 \pm 0.08(\mathrm{p}<0.05)$. These data indicate an improvement in blood flow, but this improvement was more related to the effects of surgical treatment with the elimination of the pathological process. Changes in the index of the opposite healthy kidney were as follows. On the renal artery, its value was $0.53 \pm 0.04(\mathrm{p}<0.02)$ against the initial value of $0.57 \pm 0.06(\mathrm{p}<0.02)$, on segmental arteries $-0.28 \pm 0.04(\mathrm{p}<0.05)$ against $0.31 \pm 0.06(\mathrm{p}<0.02)$, and on the interosseous arteries $-0.29 \pm 0.06$ $(p<0.05)$ against $0.31 \pm 0.06(p<0.02)$. For convenience of comparison of the received data we used relative values of the indicator with its conversion in percentage. That is, the relative decrease in the index of resistance of bleeding of the affected kidney by $2,63 \pm 0,09 \%(p<0,05)$ and contralateral kidney by $5,17 \pm 1,1 \%(\mathrm{p}<0,05)$ systematically noted improvement of the total index and the kidney blood flow was $7.8 \pm 0.2 \%(\mathrm{p}<0.05)$.

Therefore, the use of medication correction of blood flow in the kidneys of patients with unilateral lesions in the perioperative period allows not only to improve it by $7.8 \pm 0.2 \%$, but also to create favorable conditions for adequate adaptive-compensatory reactions to the restoration of the functional state of both kidneys.

\section{Practical recommendations}

1. Practically, the knowledge of the shredded method of modeling the post-mortem nibi of other creatures is experimented on the basis of the dosed, lower cost of omnipotent versus parenchyma of indifferent outcomes.

2. For correcting the reduction of blood flow in parenchyma niri in ill people with one and the same fever, it is recommended that 3 addons be extended by 2 times, if surgery is necessary, it may be necessary to increase the risk of adrenal hypertrophy. a 3-d stretch of preventive maintenance - anticoagulant groups of low-molecular-weight heparins, and a 2-fold prolonged period of treatment - antiplatelet agents (vinpocetine, pentoxifyl).

3. To control the incidence of reduced blood circulation in parenchyma and corrected secondary therapy in patients with advanced ultrasound therapy, they are required to receive additional. 


\section{References:}

1. Stus V.P. (2013). Stan krovoobihu parenkhimy nyrok u khvorykh zi stiikym porushenniam urodynamiky [State of renal parenchyma circulation in patients with persistent urodynamic disorders]. Urology. Ukrainian Medical Journal, no 3, pp. 17-19.

2. Stus V.P., Barannik K.S., Shponka I.S., Poslavskaya O.V. (2014). Doslidzhennya modeley odnostoronnikh patolohichnykh protsesiv porushennya mistsevoho nyrkovoho krovoobihu $\mathrm{z}$ metoyu vyznachennya zmin stanu kontralateral'noyi nyrky: imunomorfolohichni aspekty [Investigation of models of unilateral pathological processes of impaired local renal circulation to determine changes in the state of the contralateral kidney: immunomorphological aspects]. Morphology. Ukrainian Medical Journal, vol. 8, no. 4, pp. 43-50.

3. Stus V.P., Barannik K.S. (2015). Kompensatorni mozhlyvosti protylezhnoyi nyrky pry riznykh vydakh odnobichnoho porushennya krovoobihu v eksperymenti [Compensatory possibilities of the opposite kidney in different types of unilateral circulatory disorders in the experiment]. South Ukrainian medical scientific journal, no. 10(10) January, pp. 86-88.

4. Stus V.P., Barannik K.S., Shponka I.S., Poslavskaya O.V. (2015). Porushennya mistsevoho nyrkovoho krovotoku pry modelyuvanni odnostoronnikh patolohichnykh protsesiv u nyrkakh [Disorders of local renal blood flow in the simulation of unilateral pathological processes in the kidneys]. Urology. Ukrainian Medical Journal, no. 3, pp. 29-36.

5. Barannik K.S. (2015). Zminy mikrotsyrkulyatornoho rusla parenkhimy ta nyrkovoho krovotoku shchuriv v umovakh eksperymental'noyi ishemiyi odniyeyi nyrky [Changes in the microcirculatory bed of the parenchyma and the renal blood flow of rats in experimental ischemia of one kidney]. South Ukrainian medical scientific journal, September 12(12), pp. 15-17.

6. Stus V.P., Sheepdog K.S. (2016). Funktsional'nyy stan i kompensatornoprystosovni mozhlyvosti parnoho orhana - nyrok $\mathrm{v}$ umovakh odnobichnoho urazhennya abo yedynoyi nyrky, shcho zalyshylasya pislya nefrektomiyi (ohlyad literatury) [Functional state and compensatory and adaptive capacity of paired organ kidney in conditions of unilateral lesion or single kidney remaining after nephrectomy (literature review)]. Urology. Ukrainian Medical Journal, no 1(76), pp. 5-16.

7. Stus V.P., Yehalov V.V., Barannik K.S., Kryzhanovsky I.D. (2016). Medykamentozna reabilitatsiya porushen' krovotoku $\mathrm{v}$ perioperatsiynomu periodi $\mathrm{u}$ patsiyentiv $\mathrm{z}$ odnobichnym patolohichnym urazhennyam nyrok [Medicinal rehabilitation of blood flow disorders in the perioperative period in patients with unilateral renal pathology]. South Ukrainian Medical Scientific Journal, no. 14(14), May, pp. 5-8.

8. Barannik K.S. (2016). Kompensatornyye sosudistyye reaktsii u patsiyentov s odnostoronnim stoykim narusheniyem urodinamiki [Compensatory vascular responses in patients with unilateral persistent urodynamic disorders]. Young Scientist. Ukrainian Medical Journal, no. 8(35), pp. 186-189.

9. Stus V.P., Barannik K.S., Yekhalov V.V., etc. (2016). Medykamentozna korektsiya porushen' krovotoku u patsiyentiv $\mathrm{z}$ odnobichnym patolohichnym urazhennyam nyrok u perioperatsiynomu periodi [Medication correction of 
blood flow disorders in patients with unilateral pathological renal injury in the perioperative period]. Urology. Ukrainian Medical Journal, no. 3(78), pp. 89-94.

10. Barannik K.S. (2016). Dynamika zmin nyrkovoho krovotoku pry odnobichnomu urazhenni nyrok $\mathrm{v}$ eksperymenti ta yikh vplyv na stan nyrok $\mathrm{u}$ viddalenomu periodi [Dynamics of changes in renal blood flow in unilateral renal injury in the experiment and their effect on the condition of the kidneys in the distant period]. South Ukrainian medical scientific journal, September 15(15), pp. 13-16.

11. Stus V.P., Barannik K.S., Yehalov V.V., Ukrainian E.P. (2016). Sposib perioperatsiynoyi korektsiyi porushen' krovotoku u patsiyentiv $\mathrm{z}$ odnobichnym patolohichnym urazhennyam nyrok [The method of perioperative correction of blood flow disorders in patients with unilateral renal pathology]. Proceedings of the Scientific and Practical Conference "Urology, Andrology, Nephrology - 2016" / Ed. V.M. Forest, I.M. Anthony and others. Kharkiv. Ukrainian Medical Journal, pp. 211-212.

12. Stus V.P., Barannik K.S. (2016). Vyvchennya stanu krovotoku nyrok za stvorenoyu novym sposobom eksperymental'noyi modeli tryvaloyi ishemiyi nyrky [The study of the state of the blood flow of the kidneys by a new way of experimental model of long-term ischemia of the kidney]. Proceedings of the Scientific and Practical Conference "Urology, Andrology, Nephrology" - 2016 "/ Ed. V.M. Forest, I.M. Anthony and others. Kharkiv. Ukrainian Medical Journal, pp. 305-306.

13. Stus V.P., Barannik K.S., Shponka I.S., Poslavskaya A.V. (2015). Narusheniye mestnogo pochechnogo krovotoka pri modelirovanii odnostoronnikh patologicheskikh protsessov v pochkakh [Disruption of local renal blood flow in the simulation of unilateral pathological processes in the kidney]. Urology. Ukrainian Medical Journal, no. 2, p. 84.

14. Barannik K.S. (2015). Stan nyrkovoho krovotoku v umovakh eksperymental'noyi ishemiyi odniyeyi nyrky [The state of renal blood flow in experimental ischemia of one kidney]. Ukrainian Scientific and Medical Youth Journal. Special issue, no. 3(90), p. 96.

15. Barannik K.S. (2014). Hemodynamika parenkhimy nyrok u khvorykh iz odnobichnym porushennyam urodynamiky [Changes in blood circulation in the renal parenchyma in experimental ischemia of one of them]. Proceedings of the International Scientific and Practical Conference "Pharmaceutical and Medical Sciences: Topical Issues" (Dnipropetrovsk, May 16-17, 2014) Ukrainian Medical Journal, pp. 40-42.

16. Stus V.P., Barannik K.S., Trofimov M.V. (2014). Medicamentous correction of kidney blood-groove and perioperation of the period. The 18th European Society of Surgery (ESS) Meeting \& The 17th Spring Annual Congress of the Lebanese Society for General Surgery (LSGS), p. 53.

17. Barannik K.S. (2016). Morfolohichna ta imunohistokhimichna kharakterystyka nyrok shchuriv iz odnobichnym stiykym porushennyam krovoobihu [Morphological and immunohistochemical characteristics of rat kidneys with unilateral persistent circulatory disorders]. Theoretical and practical aspects of the development of modern medicine. Collection of abstracts of scientific works of participants of the international scientific-practical conference (Lviv, June 24-25, 2016). Lviv: NGO "Lviv Medical Community", pp. 20-24. 